\title{
PLATFORM MICROSITE : KONVERGENSI MEDIA PUBLIKASI KEMENTERIAN KEUANGAN RI DI ERA LITERASI DIGITAL
}

\author{
Aditya Arifiyanto, Prahastiwi Utari, dan Andre Noevi Rahmanto \\ aditya.arf@student.uns.ac.id \\ Universitas Sebelas Maret
}

\begin{tabular}{l} 
Article Info \\
\hline Keyword: \\
Media Convergence, Digital Litera- \\
cy, Public Relations Innovations
\end{tabular}

\section{PENDAHULUAN}

Kemajuan ilmu pengetahuan dan teknologi yang mengalami perkembangan pesat pada masa kini memberikan peran dalam membantu manusia dalam memasuki zaman baru di era teknologi sekarang ini. Perkembangan teknologi dapat membantu aktivitas manusia didalam kehidupan sehari-hari, termasuk dalam membantu manusia untuk memperoleh informasi yang cepat, tepat, akurat, aktual dan dapat dipercaya terhadap suatu isu tertentu. Teknologi juga mengalami perkembangan yang signifikan dari masa ke masa. Munculnya teknologi baru (pembaharu teknologi sebelumnya) dapat berim-plikasi positif maupun negatif pada berbagai bidang kehidupan, termasuk dalam pola komunikasi dan tren masyarakat dalam bermedia massa (Supadiyanto, 2013).

Adanya kemajuan teknologi informasi dan internet saat ini memberikan dampak kepada peningkatan sumber daya informasi digital. Dengan begitu, semua orang dapat secara bebas sesuai dengan keinginan dan preferensinya untuk memilih serta menikmati media digital mana yang dirasa menarik untuknya. Kondisi tersebut memunculkan istilah digital native, yang berarti bahwa generasi saat ini hidup pada era digital, yakni dimana internet menjadi bagian dari keseharian dalam hidupnya (Kurnianingsih, I., Rosini, Ismayati, N. 2017). Peru diinformasikan pula bahwa di Indonesia ini termasuk dalam negara yang aktivitas internetnya terbilang cukup tinggi, terlebih lagi pada generasi muda rentang 18-20 tahun yang merupakan pengguna teknologi paling aktif (Norhabiba, 2015). Akses terhadap mesin pencarian Google juga menjadi aktivitas rutin yang dilakukan oleh warga net dalam beraktifitas di internet.

Selain adanya mesin pencari Google sebagai kanal awal jendela informasi digital, hadir pula media sosial dan bermacam-macam platform website yang memenuhi dunia digital masa kini. Keanekargaman bentuk dan jenis informasi ini seharusnya dapat mendorong masyarakat digital agar dapat selektif dan 
mempunyai kemampuan untuk mengoptimalkan penggunaan berbagai macam media digital tersebut.

Kemudian, dari melimpahnya media digital dalam pencarian informasi yang dihadirkan di dunia maya, muncul istilah literasi digital. Literasi digital dapat dikatakan salah satu bentuk literasi media, dimana literasi media disebutkan berfungsi agar dapat menangkal pengaruh buruk media dengan penguasaan kemampuan, penguasaan dan keterampilan untuk menggunakan media komunikasi (Setyowati, 2002). Lalu melalui perkembangan literasi media, muncullah istilah literasi digital untuk menjelaskan kemampuan manusia menghadapi media digital. Istilah literasi digital dikemukakan pertama kali oleh Paul Gilster (1997) sebagai kemampuan memahami dan menggunakan informasi dari berbagai sumber digital. Ia mengemukakan bahwa literasi digital merupakan kemampuan menggunakan teknologi dan informasi dari piranti digital secara efektif dan efisien dalam berbagai konteks, seperti akademik, karier, dan kehidupan sehari-hari.

Lalu Bawden (2001) memperluas pemahaman baru mengenai literasi digital yang berakar pada literasi komputer dan literasi informasi. Perkembangan teknologi pada revolusi industri 2.0 menjadi 3.0 menjadi salah satu faktor berkembangnya literasi komputer, dimana pada revolusi industri 3.0 menekankan penggunaan internet pada komputer sebagai media dalam melakukan proses industrinya, tak terkecuali pada pencarian informasi. Perlu dipahami bahwa literasi digital bukan hanya menekankan pada kemampuan seseorang dalam memilah, menggunakan, mengkonsumsi dan menggunakan perangkat teknologi informasi dan komunikasi melalui piranti digital saja, namun terlebih penting lagi adalah bagaimana proses seseorang membuat perangkat teknologi agar dapat menarik dan digunakan seseorang sehingga dapat menciptakan budaya literasi digital.

Berdasarkan hasil analisa oleh situs We Are Social dan Hootsuite's Digital 2017, dari total penduduk Indonesia sekitar 262,0 juta jiwa, dan sebanyak 132 juta jiwa (51\% dari populasi penduduk) merupakan pengguna internet aktif. (https://wearesocial.com/ special-reports/digital-southeast-asia-2017). Data ini memang tidak dapat secara langsung menggambarkan perkembangan teknologi informasi sejak kelahiran internet dan media baru, namun dari data tersebut kita dapat menarik kesimpulan bahwa keterlibatan penggunaan teknologi informasi di Indonesia dapat dikatakan lumayan tinggi. Banyaknya penduduk yang aktif menggunakan internet juga merupakan keuntungan dari faktor demografi Indonesia, sehingga potensi tersebut dapat mempengaruhi peta strategi komunikasi.

Dalam organisasi, humas memiliki peran penting sebagai alat manajemen komunikasi modern, maka dalam organisasi diperlukan adanya humas yang secara struktural merupakan bagian integral dari suatu kelembagaan atau organisasi (Nubatonis, 2015). Hal ini diterapkan oleh Kementerian Keuangan (Kemenkeu) sebagai instansi pemerintah melalui Biro Komunikasi dan Layanan Informasi (Biro KLI) Kemenkeu RI. Biro KLI Kemenkeu merupakan suatu Biro struktural yang berada dibawah Sekretariat Jenderal Kemenkeu, dimana Biro KLI mempunyai tugas mengoordinasikan dan melaksanakan pembinaan dan manajemen kehumasan di lingkungan Kementerian sesuai dengan peraturan perundang-undangan yang berlaku. Menurut Peraturan Menteri Keuangan (PMK) 234/ PMK.01/2015 beberapa fungsi Biro KLI yaitu, pembinaan aktivitas komunikasi dan layanan informasi kebijakan pengelolaan keuangan dan kekayaan negara serta kebijakan Kementerian di bidang lainnya dan penyelenggaraaan publikasi cetak dan elektronik.

Kemenkeu menyadari bahwa teknologi dengan segala inovasinya merupakan sebuah keniscayaan, sama halnya dengan penggunaan new media untuk keperluan berkomunikasi. Biro KLI Kemenkeu RI, selaku struktur birokrasi Kemenkeu yang menangani fungsi kehumasan memberikan respon terhadap perubahan tersebut. Memperbanyak media publikasi melalui media digital dengan memanfaatkan penggunaan platform website dan media sosial merupakan hal yang harus dilakukan. Dengan begitu, dengan banyaknya media yang dikelola oleh Biro KLI diharapkan dapat mempublikasikan kebijakan dan informasi serta mengedukasi masyarakat terkait kebijakan keuangan negara secara mudah, menarik dan tepat sasaran.

Lee (2012) menekankan bahwa tujuan dari ak- 
tivitas hubungan masyarakat pemerintah adalah untuk memenuhi tanggung jawabnya salah satunya dengan cara memberikan informasi dan layanan yang diperlukan kepada warga negara dan dengan merespons kebutuhan mereka. Mengingat pentingnya hal itu, beberapa undang-undang, seperti Undang-Undang Keterbukaan Informasi Publik, mentitahkan pemerintah untuk mengambil tanggung jawab ini, dengan memastikan warga negara dapat mengakses informasi pemerintah dan dapat meminta tanggapan dari pemerintah terhadap tuntutan eksternal (Grimmelikhuijsen \& Welch, 2012). Munculnya website diharapkan dapat menyediakan lebih banyak fitur kepada pemerintah untuk memenuhi tanggung jawabnya tersebut dengan lebih baik.

Website merupakan salah satu bentuk dari new media yang menawarkan kemudahan dalam pemberian maupun pencarian informasi. Website adalah halaman informasi yang disediakan melalui jalur internet sehingga bisa diakses di seluruh dunia selama terkoneksi dengan jaringan internet. Secara analogi, website merupakan sebuah wujud identitas sebuah lembaga didunia digital, melalui website, institusi atau lembaga dapat dikenal lalu membentuk citra yang mereka bawa kepada masyarakat. Melalui website, pemerintah dapat meningkatkan transparansi dan efisiensinya terhadap informasi dan layanan penyampaian dan juga memastikan kerja sama antar dan antar lembaga (Sadeghi, 2012).

Kemenkeu juga mengaplikasikan website sebagai pembentuk citra di dunia digital. Dengan berisikan informasi yang dapat di akses secara bebas oleh publik, website kemenkeu berfungsi juga sebagai sumber referensi informasi dan segala peraturan mengenai pengelolaan keuangan negara. Namun banyaknya fitur dan jenis konten yang dapat di unggah pada website Kemenkeu menimbulkan masalah baru, apakah website tersebut sudah memberikan fokus pada konten atau isu tertentu yang layak diangkat? Apakah dengan penggunaan kanal media digital Kemenkeu lainnya sudah dapat mengakomodir kebutuhan tersebut?

Selain website Kemenkeu juga menggunakan media sosial sebagai media dalam berhubungan dengan masyarakat dalam usahanya untuk memberikan infor- masi dan menampung pertanyaan yang timbul dari masyarakat. Hal ini dilakukan karena Kemenkeu percaya bahwa media sosial telah memainkan peran yang semakin penting dalam komunikasi dua arah antara pemerintah dan masyarakat. Karena media sosial didasarkan pada keterhubungan pengguna melalui komunikasi langsung dengan berbagi informasi, pendapat, dan ide. Komunikasi pemerintah-masyarakat melalui media sosial memiliki peluang lebih besar menjadi dialogis dan interaktif. Saluran media sosial yang umum mencakup blog, Facebook, Twitter, Wikipedia dan Youtube (Sadeghi, 2012; Wilcox, Cameron, Reber, \& Shin, 2011). Sebagai contohnya adalah blog, blog merupakan bukan lagi suatu hal yang baru. Banyak pula masyarakat Indonesia yang memiliki dan menggunakan blog dalam berjejaring sosial. Aktivitas ini ini mencerminkan adanya sifat keterbukaan dan kebebasan pertukaran informasi dan juga biasanya pada sebuah blog terdapat kolom tersendiri untuk saling berkomentar dan bertukar pendapat (Fithryani, 2015).

Hal ini merupakan nilai tambah bagaimana warganet berjejraning sosial melalui media baru di internet. Selain blog ada pula media sosial, media sosial bisa diakses dengan mudah melalui smartphone oleh semua masyarakat kapan saja. Semua orang dapat mengirimkan berbagai pesan dalam format digital yang beraneka ragam, baik dalam bentuk foto, video ataupun teks sehingga dapat mempengaruhi follower atau pemakai media sosial lainnya (Umami, 2015). Dengan penggunaan bermacam macam media digital tersebut dapat dikatakan teknologi digital baru muncul dalam menyusun dan mengirim teks terus berkembang, menghadirkan peluang baru dan tantangan untuk dapat mengembangkan literasi digital (Sabatino, 2014). Pada dunia virtual yang menghasilkan informasi ini tidak naya berdiam diri, tetapi dapat menginvasi dunia nyata.

Namun dunia digital sangat bergantung kepada, tindakan yang dilakukan manusia berdasarakan kebebasan pilihan dan pemahaman mereka. Teknologi hanyalah sebuah alat yang tidak dapat menentukan bagaimana kita harus bertindak, semuanya itu tergantung pada manusia itu sendiri. Pada tingkat konsumsi media yang tinggi, masyarakat akan dipenuhi oleh media. Media itu sangat memengaruhi persepsi, kepercayaan, dan sikap. Penyajian informasi melalui kon- 
ten visual pada era ini sangat menguntungkan, dapat memberikan perspektif yang lebih jelas terhadap penyampaian informasi (Koltay, 2011). Visual komunikasi dan informasi ini akan semakin meningkat seiring dengan perkembangan teknologi dan budaya digital masyarakat.

Penggunaan beragam media dalam pelaksanaan kegiatan kehumasannya menunjukkan bahwa Kemenkeu memberikan fasilitas kepada masyarakat agar dapat memilih media mana yang dirasa sesuai dengan pribadi masyarakat masing-masing. Penggunaan media yang bermacam-macam untuk memperoleh tujuan tertentu seperti yang dilakukan oleh Biro KLI Kemenkeu dapat dikatakan sebagai konvergensi media. Karena konvergensi media membuat khalayak memiliki lebih banyak pilihan media dengan konten yang semakin beragam pula (Grant dan Wilkinson, 2009). Konvergensi merupakan saat dimana sudah tidak ada pembatas perbedaan lagi di antara satu jenis media dengan media yang lainnya. Konvergensi dikatakan sebagai saat di mana hilangnya batas perbedaan antarmedia (Baran \& Davis, 2010).

Melalui penjelasan sebelumnya kita dapat menarik kesimpulan bahwa dalam melakukan pelayanan dalam hal pemberian informasi keuangan negara kepada masyarakat, Biro KLI Kemenkeu telah menggunakan bermacam-macam platform media sebagai media publikasinya. Media tersebut terdiri dari website dan media sosial, namun apakah hanya dengan menggunakan media tersebut Biro KLI Kemenkeu sudah melakukan tugasnya dalam memberikan pemberian informasi kepada masyarakat melalui media digital tersebut? Adakah inovasi terhadap konvergensi media dalam penggunaan media digital untuk publikasi informasi yang mengadopsi karakter literasi digital yang dilakukan oleh Biro KLI? Bagaimanakah proses perencanaan dan pembuatan media publikasi media baru oleh Biro KLI? Apakah kemenkeu menggunakan kaidah konvergensi media dalam pembuatan media publikasi mereka yang baru? Bagaimanakah respon dari masyarakat dalam merespon inovasi penggunaan media publikasi yang baru tersebut apabila dilihat dari konsep literasi digital? Bagaimankah respon masyarakat dan insan lembaga kehumasan di indonesia dalam memberikan respon terhadap hadirnya media publikasi
Kemenkeu yang baru tersebut? Serta bagaimanakah tujuan akhir yang ingin dicapai okeh Biro KLI melalui pembuatan media publikasi baru tersebut?Melalui artikel ini penulis akan memberikan gambaran dan kesimpulan secara komprehensif mulai dari perencanaan hinggak evaluasi terkait dengan inovasi konvergensi media publikasi yang dilakukan oleh Kemenkeu di era literasi digital saat ini.

Penelitian menegenai konvergensi media sebagai bentuk penyesuaian terhadap literasi digital masyarakat telah dilakukan sebelumnya oleh Khadziq yang dipublikasikan dalam jurnal Profetik Vol. 10/No.01/April 2016, dalam artikelnya yang berjudul "KONVERGENSI MEDIA SURAT KABAR LOKAL (Studi Deskriptif Pemanfaatan Internet Pada Koran Tribun Jogja dalam Membangun Industri Media Cetak Lokal)". Dalam artikel tersebut penulis melakukan penelitian terhadap koran Tribun Jogja yang mengubah strategi bisnisnya mengikuti perkembangan zaman. Hasil dari penelitian tersebut menyebutkan bahwa keputusan Tribun Jogja untuk melakukan konvergensi media menggunakan strategi 3M (Multimedia, Multichannel dan Multiplatform). Selain itu dengan menerapkan konvergensi media, Tribun Jogja juga dapat menyampaikan berita dengan lebih cepat secara real time dengan bentuk singkat dan tampilan yang lebih populer sehingga membuat audience tertarik membaca (Khadziq, 2016)..

\section{KAJIAN PUSTAKA}

\section{Metodologi penelitian}

Penelitian ini membahas bagaimana Biro KLI Kemenkeu RI melakukan inovasi media publikasi sebagai bentuk konvergensi media dalam rangka menyesuaikan diri terhadap era literasi digital melalui pendekatan deskriptif kualitatif. Dalam penelitian kualitatif, metode yang biasanya digunakan adalah wawancara, pengamatan, dan pemanfaatan dokumen (Moleong, 2006). Untuk melakukan penelitian ini, penulis mengumpulkan data dengan menggunakan cara teknik observasi, wawancara dan dokumentasi. Pengumpulan data dengan cara observasi penulis melakukan dengan cara mengamati langsung peristiwa 
yang akan diteliti, mulai dari pengumpulan masalah, analisis masalah serta eksekusi dari analisis tersebut. Dalam pengumpulan data melalui wawancara, penulis melakukannya dengan cara wawancara semi-terstruktur dengan Kasubbag Publikasi Elektronik, Biro Komunikasi dan Layanan Informasi, Kementerian Keuangan RI selaku pemegang kebijakan dalam pengelolaan publikasi informasi pada media digital Kemenkeu RI sebagai informannya. Wawancara dilakukan dengan bertanya langsung kepada informan untuk mendapatkan informasi yang berkaitan dengan data yang dibutuhkan, yaitu memperoleh informasi bagaimana Biro KLI dalam perjalanannya untuk melakukan inovasi media publikasi baru sebagai bentuk konvergensi media dan bagaimana konsep media baru tersebut bekerja. Wawancara ini mengembangkan pertanyaan-pertanyaan dasar pada penelitian guna menggali lebih dalam lagi informasi yang dapat diperoleh. Melalui wawancara ini memungkinkan penulis untuk dapat menganalisis alasan dari Biro KLI merasa perlu mengembangkan media publikasi baru mulai dari bagaimanakah latar belakang perkembangan media publikasi digital Kemenkeu?, seperti apakah Biro KLI dalam menganalisa kebutuhan media publikasi digital yang baru?, bagaimanakah konsep desain yang diangkat oleh Biro KLI dalam merancang media publikasi yang baru?, bagaimanakah strategi penyajian konten media publikasi yang baru untuk berkomunikasi, serta bagaimankah evaluasi pada masa awal penggunaan media publikasi yang baru tersebut apabila dilihat dari respon masyarakat. Sedang untuk mendapatkan pengumpulan data dokumentasi dilakukan dengan mengambil data dari Google Analytics untuk mengambil hasil performa website dan microsite. Analisis datanya dilakukan dengan cara mengatur secara sistematis pedoman wawancara, data dokumentasi, kemudian memformulasikan secara deskriptif. Sugiyono (2005) menyatakan bahwa metode deskriptif adalah suatu metode yang digunakan untuk menggambarkan atau menganalisis suatu hasil penelitian tetapi tidak digunakan untuk membuat kesimpulan yang lebih luas.

\section{Kajian Konseptual}

Sebenarnya, kajian ilmu mengenai literasi media dapat ditemukan pada interdisipliner ilmu, bagaimana menggunakan alat dan mengggunakannya pada metode sosiologi, psikologi, teori politik, studi gender dan ras, serta studi budaya, seni, dan estetika. Karya Marshall McLuhan dan yang lainnya dalam studi komunikasi juga penting untuk hal ini. Hal ini tidak jauh berbeda dalam hal literasi teks yang berfokus bagaimana orang memahami, menafsirkan, menganalisis secara kritis dan menulis teks menjadi subjek penelitian di bidang teori sastra, studi budaya, sejarah, psikologi, perpustakaan dan ilmu informasi, kedokteran dan kesehatan masyarakat, linguistik, retorika, komunikasi dan studi media (Koltay, 2011).

Literasi media dapat dikatakan juga induk dari literasi digital, dimana literasi gigital lebih memfokuskan pada media yang menggunakan teknologi digital. Literasi digital dikemukakan pertama kali oleh Paul Gilster (1997) sebagai kemampuan memahami dan menggunakan informasi dari berbagai sumber digital. Ia mengemukakan bahwa literasi digital merupakan kemampuan menggunakan teknologi dan informasi dari piranti digital secara efektif dan efisien dalam berbagai konteks, seperti akademik, karier, dan kehidupan sehari -hari. Lalu Bawden (2001) memperluas pemahaman baru mengenai literasi digital yang berakar pada literasi komputer dan literasi informasi. Perkembangan teknologi pada revolusi industri 2.0 menjadi 3.0 menjadi salah satu faktor berkembangnya literasi komputer, dimana pada revolusi industri 3.0 menekankan penggunaan internet pada komputer sebagai media dalam melakukan proses industrinya, tak terkecuali pada pencarian informasi.

\section{TEMUAN DAN DISKUSI}

\section{Perkembangan Media Publikasi Kemenkeu}

Kemenkeu sebelum menggunakan platform media sosial sebagai media publikasi seperti sekarang ini, Kemenkeu melalui Biro KLI telah menggunakan website sebagai platfom publikasinya juga. Website ini dapat dikatakan merupakan media publikasi digital internet pertama kali. Dalam pemanfaatannya, Website Kemenkeu sampai tahun 2019 telah mengalami 3 kali perubahan. Perubahan tersebut dilakukan dalam rangka 
menyesuaikan dengan teknologi informasi, trend digital serta yang sangat penting yaitu website tersebut dapat menyediakan kebutuhan mengenai penyajian informasi dengan berbagai jenis kontennya.

Lazimnya, konten yang dimiliki dari sebuah website biasanya terdiri dari 2(dua) jenis, konten statis dan konten dinamis, dimana setiap jenis konten tersebut memiliki fungsi dalam strategi komunikasinya. Konten dinamis biasanya dipakai dalam pemuatan berita, siaran pers, agenda, dan peraturan, sedang konten statis digunakan untuk informasi yang tidak terlalu menekankan pada keterbaharuan informasi, sebagai contohnya digunakan untuk memberikan informasi mengenai visi misi Kemenkeu, struktur organisasi Kemenkeu, sejarah, arti logo dan masih banyak lagi.

Dibalik itu semua, sebenarnya konten statis dari website memiliki tingkat fleksibilitas yang tinggi terhadap penyajian informasi, dapat berdiri sendiri dan seolaholah bukan bagian dari website induknya, karena dapat di-setting untuk memiliki URL sendiri. Dari sifat konten statis tersebut, maka konten statis dari website dapat digunakan sebagai landing page. Dalam pendekatan digital marketing, landing page merujuk pada sebuah laman khusus dan mandiri yang terpisah dari bagian website yang lain. Landing page didesain dan didedikasikan secara khusus sesuai dengan produk atau informasi yang ditawarkan. Kemenkeu mengadopsi pendekatan tersebut dalam rangka penyajian informasi yang bersifat sangat teknis dan khusus untuk mempublikasikannya, seperti untuk keperluan kampanye, atau edukasi informasi isu tertentu.

Untuk beberapa bulan, penggunaan landing page pada website untuk keperluan kampanye menjadi strategi andalan bagi publikasi informasi Kemenkeu, namun menurut informan, dia menemukan beberapa faktor yang mengubah pemikiran Biro KLI untuk membuat suatu media publikasi baru, adapun faktor-faktor tersebut adalah :

1. Seiring berjalannya waktu, penggunaan landing page yang menggunakan website sebagai platformnya menemui kendala karena arsitektur teknologinya yang menjadi satu domain dalam website Kemenkeu. Hal ini mempunyai konsekwensi apabila website Kemenkeu sedang mengalami masalah, maka berimbas pula pada semua landing page yang ada. Dengan demikian, memisahkan website dengan landing page menjadi bahan pertimbangan Biro KLI.

2. Pergeseran penggunaan mobile devices daripada personal computer (PC) atau laptop sebagai alat utama untuk mengakses internet mulai menjadi sebuah trend digital baru. Fakta ini di dukung pula dengan hasil analisa dari situs We Are Social yang memetakan penggunaan devices untuk mengakses internet di Indonesia pada tahun 2017. Yaitu penggunaan smartphone memiliki persentase sejumlah $69 \%$ sedangkan untuk penggunaan laptop atau PC memiliki persentase 28\% (https:// wearesocial.com/special-reports/digital-southeastasia-2017).

3. Situs We Are Social juga merilis data mengenai platform media sosial di Indonesia pada tahun 2017 yang memiliki penetrasi tinggi, data tersebut menunjukkan bahwa Youtube, Instagram dan Facebook menjadi platform media sosial yang memiliki akses tertinggi. Apabila ditelaah lebih dalam lagi, ketiga platform tersebut memiliki platform yang hampir sama, yaitu penggunaan media visual sebagai unggahan kontennya. Biro KLI menyimpulkan bahwa penggunaan media visual telah menjadi trend baru dalam pembuatan kontennya.

4. Hadirnya trend media visual dan penggunaan mobile devices sebagai perangkat yang mayoritas dipakai oleh masyarakat digital Indonesia untuk mengakses internet menimbulkan masalah baru, yaitu apakah website Kemenkeu dapat diakses dengan baik sewaktu menampilkan konten visual tersebut?. Terlebih lagi teknologi informasi untuk menampilkan konten visual sudah berkembang dengan adanya teknologi Responsive Web Design (RWD). RWD adalah pendekatan untuk desain web yang membuat halaman web dapat dirender dengan baik pada berbagai perangkat dan ukuran jendela atau layar (Tafreshi et al. 2017).

Dengan adanya pertimbangan-pertimbangan diatas, Biro KLI merasa membutuhkan media publikasi baru yang dapat menyesuaikan dengan perkembangan 
teknologi informasi dan trend digital di Indonesia, maka dari itu Biro KLI memutuskan untuk menggunakan platform microsite sebagai media baru, memberikan nama Visual Kemenkeu (VK) dan menggunakan URL yang berbeda dengan domain utama website Kemenkeu (www.kemenkeu.go.id), yaitu dengan menggunakan URL visual.kemenkeu.go.id.

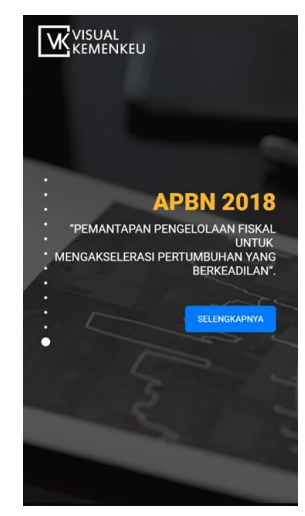

Sumber : Visual Kemnekeu, 2019 Gambar 1. Tampilan Halaman Utama VK pada
Smartphone

\section{Penggunaan Microsite Sebagai Media Publikasi Digi- tal Baru}

Microsite adalah halaman web individu atau sekelompok kecil halaman yang dimaksudkan untuk berfungsi sebagai entitas terpisah dalam situs web yang ada (Enge et al. 2009) serta halaman utama microsite dapat memiliki nama domain atau subdomain sendiri (Ash et al, 2012). Biro KLI mendesain agar VK mempunyai karakteristik khusus daripada media publikasi Kemenkeu yang lainnya, yaitu visual, fokus dan cepat. Bisa dikatakan juga VK ini dapat berisikan informasi secara lengkap seperti website kemenkeu, namun memiliki tampilan pengguna yang menarik seperti media sosial. Karakteristik visual disini diartikan bahwa konten yang akan diunggah dalam VK harus menarik dari segi visual, penggunaan graphics, multimedia dan animasi menjadi kunci utama. Selain itu setiap konten yang diunggah memiliki fokus terhadap informasi, yaitu hanya mengangkat satu isu saja untuk setiap kontennya, karena menurut Biro KLI, penyajian informasi yang fokus merupakan cara komunikasi terbaik. Kemudian yang terakhir adalah kecepatan, kecepatan disini bukan hanya masalah kecepatan VK sewaktu diakses, namun kemampuan teknologi VK dalam memproduksi suatu konten dengan cepat serta dapat diopesionalkan oleh orang biasa, tidak harus memiliki background pemprograman web. Strategi Biro KLI mengemas pesan sehingga menjadi informasi yang menarik untuk dilihat dan dapat diterima oleh masyarakat merupakan perhatian Biro KLI selanjutnya, untuk itu Biro KLI mendesain pesan komunikasi VK dalam bentuk Visual Communication.

\section{Pendekatan Komunikasi Menggunakan Visual Commu- nication}

Visual Communication (Komunikasi visual) adalah penyampaian gagasan dan informasi dalam bentuk yang dapat dilihat. Komunikasi visual sebagian atau seluruhnya bergantung pada penglihatan (Sless, 1981). Komponen desain dalam membentuk visual merupakan hal yang penting, yaitu bagaimana membuat konten yang menarik untuk VK. Desain itu sendiri adalah proses membuat dan mengkomunikasikan gagasan dalam bentuk gambar atau visual. Tujuan adanya desain adalah untuk menciptakan suatu harmoni dan mencapai satu kesatuan. Elemen-elemen desain web yang dimaksud adalah logo, icon, blok teks, warna, font, dan foto/gambar yang ada dalam suatu halaman microsite. Komunikasi visual adalah spektrum luas yang mencakup tanda, tipografi, gambar, desain grafis, ilustrasi, desain industri, iklan, animasi, warna, dan sumber daya elektronik (Smith, 2005).

Memberikan keseragaman dalam mendesain website dapat menunjukkan citra institusi yang baik. Mengingat Kemenkeu memiliki banyak instasi yang memiliki website sendiri-sendiri, Kemenkeu telah menerbitkan aturan mengenai pedoman bagaimana membuat desain website di lingkungan Kemenkeu, yaitu dengan adanya Keputusan Menteri Keuangan (KMK) Republik Indonesia No 50/KMK.01/2014 yang kemudian disempurnakan lagi melalui Keputusan Menteri Keuangan (KMK) Republik Indonesia No 458/ KMK.01/2018. Dengan demikian VK juga memiliki pedoman desain standar dalam produksinya menyesuaikan dengan KMK tersebut. Namun desain Komunikasi Visual untuk VK tidak berhenti pada aturan itu saja, karena KMK tersebut tetap memiliki fleksibilitas dalam bagaimana desainer mendesain web- 
site, oleh karena itu VK memiliki perhatian lagi terhadap fleksibilitas tersebut dengan membuat desain yang menggunakan video, animasi, foto dan gambar untuk kontennya.

\section{Strategi Penyajian Konten Visual Kemenkeu}

Visual Kemenkeu mulai digunakan sebagai media publikasi mulai bulan Oktober 2018 dengan mengangkat isu APBN 2018 sebagai konten pertamanya. Sebelumnya, informasi mengenai APBN secara komprehensif selalu disajikan oleh Biro KLI melalui halaman website Kemenkeu dan menyertakan infografisnya. Setelah hadirnya VK, maka informasi APBN dialihkan ke dalam VK, akan tetapi tetap menggunakan pendekatan visual seperti infografis dengan diberikan tambahan animasi dalam penyajiannya. Penyajian dengan multimedia bertujuan agar VK dapat memberikan User Experience yang baik kepada masyarakat, sehingga masyarakat lebih tertarik untuk mendapatkan informasi melalui media VK ini.

Penyajian menggunakan foto, gambar, video atau animasi untuk konten VK dilakukan Biro KLI sesuai dengan kebutuhan informasi konten. Sebagai contoh untuk konten APBN 2018, yang mayoritas berisi mengenai informasi pendapatan negara dan belanja negara, berarti penggunaan teks berupa angka dan deskripsi menjadi isi utama dari konten APBN 2018 ini, maka penggunaan animasi saja sudah cukup untuk memberikan kesan dinamis pada landing page ini. Mirip dengan konten APBN 2018, landing page VK dengan mengangkat isu Sejarah Oeang Republik Indonesia (ORI) mempunyai kemiripan strategi dalam penyajiannya, karena didalam landing page tersebut berisikan tentang milestones perjalanan ORI dari pertama kali ada hingga sekarang, oleh karena itu penyajiannya lebih menekankan pada animasi teks dan gambar saja. Berbeda dengan APBN 2018 dan ORI, ada pula landing page yang berisi informasi mengenai Pembiayaan Ultra Mikro (UMi). Pada landing page UMi, Biro KLI memberikan strategi yang berbeda dalam memberikan informasi mengenai UMi, yaitu dengan memasukkan video Iklan Layanan Masyarakat (ILM). Hal ini di lakukan karena pada ILM berisi mengenai testimoni masyarakat setelah menggunakan fasilitas kredit UMi, hal ini dirasa penting oleh Biro KLI karena dengan mengangkat testimoni masyarakat berarti menambah kredibilitas terhadap program kredit UMi tersebut.

\section{Evaluasi Penggunaan VK}

Selama penggunaan VK sebagai media publikasi Kemenkeu yang baru, Biro KLI tetap melakukan monitoring, mengevaluasi dan menganalisis hasilnya. Monitoring dan evaluasi merupakan salah satu cara untuk mengendalikan program, sedang menganalisa hasil dari evaluasi selain dapat mengoreksi program dengan cepat, merupakan cara untuk mendapatkan data awal yang dapat digunakan untuk menentukan langkah strategi publikasi dimasa yang akan datang. Untuk membantu memonitoring dan mengevaluasi VK, Biro KLI menggunakan bantuan dari Google Analytics. Dengan menggunakan Google Analytics, Biro KLI dapat mengetahui traffic realtime, profil pengguna, media untuk mengakses, informasi demografi dan masih banyak lagi. Sejak pertamakali peluncurannya pada 1 Oktober 2018 hingga 17 Juli 2019, pengunjung VK telah berjumalah 17.730 users dengan persentase pengunjung baru sebesar 88,5\% (Gambar 2). Dibandingkan dengan jumlah pengunjung website Kemenkeu yang pada periode yang sama dengan jumlah 2.570.455 pengunjung (Gambar 3) memang memiliki rasio yang kecil, namun banyaknya pengunjung memang bukan indikotor satu-satunya kesuksesan penggunaan VK sebagai media baru, namun dari data tersebut Biro KLI dapat mengetahui bahwa VK mendapat respon yang positif dari masyarakat dengan ditunjukkan antusiasnya masyarakat berkunjung ke microsite ini. Data dari Google Analytics juga menunjukkan bahwa, dalam mengakses VK, masyarakat menggunakan OS android dan iOS sebagai sistem operasi yang paling populer digunakan (Gambar 4). Hal ini menunjukkan bahwa strategi Biro KLI untuk membuat media publikasi baru dengan trend digital, yaitu trend penggunaan mobile devices sebagai perangkat untuk mengakses internet.

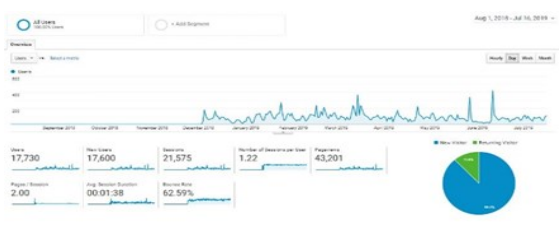

Sumber : Google Analytic, 2019

Gambar 2. Tampilan Laporan Visual Kemenkeu 2019 


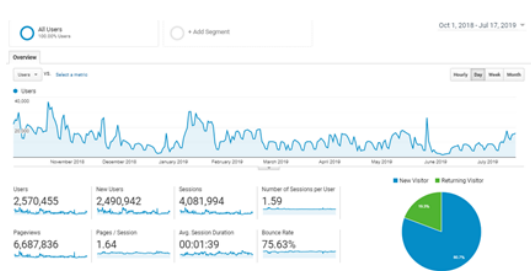

Sumber : Google Analytic, 2019

Gambar 3. Tampilan Laporan Website Kemenkeu 2019

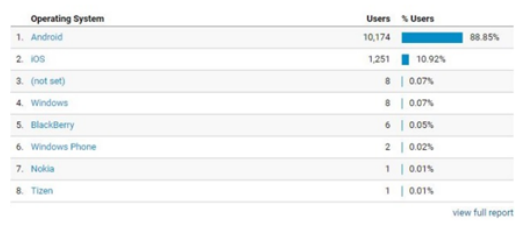

Sumber : Google Analytic, 2019

Gambar 4. Tampilan Laporan OS Pengunjung VK 2019

\section{KESIMPULAN}

Disamping penggunaan website dan media sosial, digunakannya VK melalui platform microsite oleh Biro KLI membuat media publikasi digital Kemenkeu menjadi lebih lengkap. Dengan begitu perencanaan strategi publikasi digital akan memberikan suasana baru, yaitu menggunakan multi platform namun dalam pelaksanaannya semuanya platform memiliki tujuan yang sama dalam mempublikasikan kontennya. Hal ini sesuai dengan tujuan dari praktek penggunaan konvergensi media, dimana Konvergensi secara prakteknya dilakukan dengan penggunaan berbagai platform media untuk satu tujuan tertentu (Vebryanda et al, 2017). Selain itu, sebagaimana desain VK yang dapat menampilkan berbagai jenis konten digital dalam satu landing page VK meliputi, text, video, foto, gambar, dan animasi, menjadi bukti bahwa dalam perancangan VK, berbagai jenis konten dapat melebur dalam satu media. Desain seperti ini juga membuktikan bahwa, konvergensi media pada VK dikatakan sebagai saat di mana hilangnya batas perbedaan antarmedia (Baran \& Davis, 2010).

Sedang apabila ditelaah melalui data dari Google Analityc, banyaknya respon masyarakat dalam mengakses VK sejak Oktober 2018 sampai dengan Juli 2019 menunjukkan bahwa VK dapat diterima oleh masyarakat dalam membantu untuk membentuk literasi digital masyarakat. Dimana Literasi digital dapat dikatakan sebagai kemampuan dan kompetensi yang menunjukkan, menemukan, mengevaluasi, dan menerima atau menolak informasi pada penggunaan media digital dan internet (Fieldhouse \& Nicholas, 2008).

Selain itu Biro KLI selaku pelaksana kegiatan kehumasan Kemenkeu ingin mengukur bagaimana seberapa baik kegiatan kehumasan yang telah dilaksanakan dengan mengikuti berbagai ajang penilaian kegiatan kehumasan ditingkat nasional dan internasional. Pada skala nasional, setiap tahun Biro KLI selalu mengikuti ajang Anugrah Media Humas (AMH) yang diadakan oleh Kementerian Komunikasi dan Informatika (Kominfo) Republik Indonesia untuk penilaian formal dan Publik Relations Indonesia Award (PRIA) untuk penilaian dari sektor informalnya. Hasilnya untuk website Kemenkeu memperoleh Silver Award untuk PRIA 2019 dan pada Anugrah Media Humas 2018 menjadi Juara 1 untuk kategori Pelayanan Informasi Melalui Internet (Website). Dengan demikian VK selaku microsite yang merupakan bagian dari website Kemenkeu dinilai memberikan inovasi yang baik dalam upaya memberikan informasi secara digital kepada masyarakat.

Penggunaan berbagai jenis platform media digital oleh Kemenkeu dalam rangka menjalankan tanggung jawab dan tugasnya sebagai salah satu lembaga negara untuk mengimplementasikan Undang Undang Keterbukaan Informasi Publik telah dijalankan melalui website, microsite dan media sosial. Meskipun menggunakan platform yang berbeda yang dapat menyebabkan variasi penyajian pesan atau informasi secara visual kepada masyarakat, penggunaan multiplatform ini tetaplah menganut strategi integrasi isu konten yang diangkat, dengan begitu penyampaian informasi akan lebih dapat dinikmati masyarakat dalam berbagai macam segmentasi.

Penulis menemukan bahwa pada era literasi digital saat ini, para penguna teknologi informasi akan tertarik dengan media yang menggunakan pendekatan secara visual yang baik untuk dilihat, dan keputusan Biro KLI untuk menambahkan microsite sebagai media publikasi baru untuk memberikan pilihan alternatif 
kepada masyarakat dapat berpotensi menambah kualitas literasi digital masyarakat, hal ini dibuktikan dengan data yang diperoleh melalui Google Analytic dan lomba penilaian kegiatan kehumasan oleh Kominfo dan PR Indonesia. Dengan beradaptasi dengan trend digital pada tahun 2017-2018, Biro KLI dapat berinovasi dalam mempublikasikan kebijakan dan informasi keuangan negara dengan menciptakan VK.

Penggunaan VK sebagai media publikasi baru Kemenkeu akan memberikan dampak kepada dinamisnya strategi komunikasi digital Kemenkeu. Melalui penggunaan VK Biro KLI dapat memberikan informasi dengan lebih fokus lagi kepada masyarakat. Sebagai informasi, Kemenkeu memiliki berbagai unit Eselon I yang berhubungan langsung dengan masyarakat, seperti pelayanan pajak, pelayanan bea masuk, pelayanan lelang ataupun pelayanan perbendaharaan negara. Untuk penelitian selanjutnya, diharapkan dapat mengupas lebih dalam lagi bagaimana inovasi Kemenkeu dalam beradaptasi dengan perkembangan teknologi informasi dan trend teknologi bukan hanya karena tanggung jawab atas transparansi informasi kepada masyarakat, namun juga terhadap teknologi informasi pelayanan publik kepada masyarakat.

\section{DAFTAR PUSTAKA}

Ash,T., Ginty, M., Page, R., Wiley,J \& Sons. (2012). Landing Page Optimization: The Definitive Guide to Testing and Tuning for Conversions.

Baran, S. J. \& Davis, D. K. (2010). Teori komunikasi massa. Dasar, pergolakan dan masa depan. Terjemahan Afrianto Daud. Jakarta: Salemba Humanika.

Bawden, D. (2001). Information and Digital Literacy: A Review of Concept. Journal of Documentation , 52 (2), pp 281-159.

Digital in Southeast Asia in 2017. (2017). Tersedia dari: https://wearesocial.com/special-reports/digitalsoutheast-asia-2017.

Enge, E., Spencer, S., Fishkin, R., \& Stricchiola, J. (2009). The Art of SEO. O'Reilly Media, Inc.

Fieldhouse, M. \& Nicholas, D. (2008). Digital Literacy as Information Savvy: The Road to Information Litera- cy.

Kurnianingsih, I., Rosini, dan Ismayati, N. (2017). Upaya Peningkatan Kemampuan Literasi Digital bagi Tenaga Perpustakaan Sekolah dan Guru di Wilayah Jakarta Pusat Melalui Pelatihan Literasi Informasi. Jurnal Pengabdian kepada Masyarakat, 3(1), pp. 6176.

Gilster, P. (1997). Digital Literacy. New York: Wiley. Grimmelikhuijsen, S. G., \& Meijer, A. J. (2012). The effects of transparency on the perceived trustworthiness of a government organization: Evidence from an online experiment. Journal of Public Administration Research and Theory, 1-21.

Grant, A.E. \& Wilkinson, J.S. (2009). Understanding Media Convergence: The State of the Field. New York: Oxford University Press.

Khadziq. (2016). Konvergensi Media Surat Kabar Lokal. Profetik, 10(1), pp. 5-20.

Koltay, T. (2011). The media and the literacies: Media literacy, information literacy, digital literacy. Media, Culture \& Society, 33(2), 211-221.

Lee, M. (2012). Government public relations: What is it good for? In M. Lee, G. Neeley, \& K. Stewart (Eds.). The practice of government public relations, pp.9-25.

Moleong, J, L. (2006). Metodologi Penelitian Kualitatif. Bandung: PT. Remaja.

Norhabiba, F. (2015). Akses Media Baru Oleh Remaja SMA Kota Semarang dan Hubungannya Dengan Interaksi Dengan Lingkungan Sekitar Pada Siswa Kelas X SMA 5 Kota Semarang. Interaksi: Jurnal Ilmu Komunikasi, 4(2), 132-138.

Nubatonis, S. I. PERAN PUBLIC RELATION DALAM PROGRAM LARASITA BADAN PERTANAHAN KABUPATEN TIMOR TENGAH UTARA DI KELURAHAN KEFA TENGAH. Interaksi: Jurnal Ilmu Komunikasi, 4(1), 62-72.

Peraturan Menteri Keuangan No 50 Tentang Standar Tampilan Situs Di Lingkungan Kementerian Keuangan. (2014). Kementerian Keuangan Republik Indonesia. Peraturan Menteri Keuangan No 234 Tentang Organisasi Dan Tata Kerja Kementerian Keuangan. (2015). 
Kementerian Keuangan Republik Indonesia.

Peraturan Menteri Keuangan No 458 Tentang Standar

Tampilan Situs Di Lingkungan Kementerian. (2018).

Kementerian Keuangan Republik Indonesia.

Sadeghi, L. (2012). Web 2.0. In M. Lee, G. Neeley, \& $\mathrm{K}$. Stewart (Eds.). The practice of government public relations, pp. $25-140$.

Setyowati, R. M. (2013). Memahami Pengalaman Literasi Media Guru PAUD Studi Kasus pada Gugus Matahari Kecamatan Bandungan, Kabupaten Semarang. Interaksi: Jurnal Ilmu Komunikasi, 2(1), 22-29.

Sless, D. (1981). Learning and Visual Communication. Smith, K,L. (2005). Handbook of Visual Communication: Theory, Methods, and Media.

Supadiyanto, S. (2013). Implikasi TECMIIN

(Technological Mind Iinterpersonal Interconecting) terhadap Peradaban \& Tren Komunikasi Manusia. Interaksi: Jurnal Ilmu Komunikasi, 2(1), 70-77.

Tafreshi, Amir E., Sarabadani, Marbach, K., Norrie, \& Moira C. (2017). Proximity-Based Adaptation of Web Content on Public Displays. International Conference on Web Engineering (ICWE):Web Engineering. Lecture Notes in Computer Science. 10360. pp. 282-301. Umami, Z. (2015). Social Strategy Pada Media Sosial Untuk Promosi Pariwisata Daerah Istimewa Yogyakarta. Interaksi: Jurnal Ilmu Komunikasi, 4(2), 195-201.

Vebrynda, R., Maryani, E., \& Abdullah, A. (2017).

Konvergensi Dalam Program Net Citizen, Jurnal

Kajian Komunikasi, 5 (1), pp. 53-68.

Wilcox, D. L., Cameron, G. T., Reber, B. H., \& Shin, J. -H. (2011). Think public relations. Boston, MA: Pearson Education. 